RASĀYAN J. Chem.

Vol. 14 | No. 3 |1514-1520| July - September | 2021 ISSN: 0974-1496 | e-ISSN: 0976-0083 | CODEN: RJCABP http://www.rasayanjournal.com RJC http://www.rasayanjournal.co.in

\title{
SYNTHESIS AND CHARACTERIZATION OF ZINC (II) COMPLEXES WITH PYRUVIC ACID SALICYLHYDRAZONE
}

\author{
Swati Jain and Bidya S. Joshi ${ }^{\bowtie}$ \\ Department of Chemistry, University of Rajasthan, Jaipur 302004 Rajasthan, India \\ ${ }^{\square}$ Corresponding Author: bsj_jaipur@yahoo.in
}

\begin{abstract}
The ligand N-(2-propionic acid)-salicyloylhydrazone(HL) and its new mixed ligand Zinc(II) complexes were synthesized and characterized by mass spectroscopy, IR spectroscopy and biological spectroscopy. The new mixed ligand Zinc complexes are $\mathrm{Zn}\left(\mathrm{C}_{5} \mathrm{H}_{5} \mathrm{~N}\right)\left(\mathrm{C}_{10} \mathrm{H}_{9} \mathrm{~N}_{2} \mathrm{O}_{4}\right) \mathrm{C}_{2} \mathrm{H}_{3} \mathrm{O}_{2}, \mathrm{Zn}\left(\mathrm{C}_{10} \mathrm{H}_{8} \mathrm{~N}_{2}\right)\left(\mathrm{C}_{10} \mathrm{H}_{9} \mathrm{~N}_{2} \mathrm{O}_{4}\right), \mathrm{Zn}_{(}\left(\mathrm{C}_{5} \mathrm{H}_{8} \mathrm{~N}_{2}\right)_{3}\left(\mathrm{C}_{10} \mathrm{H}_{9} \mathrm{~N}_{2} \mathrm{O}_{4}\right)$, $\mathrm{Zn}\left(\mathrm{C}_{10} \mathrm{H}_{9} \mathrm{~N}_{2} \mathrm{O}_{4}\right)\left(\mathrm{C}_{9} \mathrm{H}_{6} \mathrm{NO}\right)\left(\mathrm{H}_{4} \mathrm{O}_{2}\right)$ and $\mathrm{Zn}\left(\mathrm{C}_{10} \mathrm{H}_{9} \mathrm{~N}_{2} \mathrm{O}_{4}\right)\left(\mathrm{C}_{14} \mathrm{H}_{11} \mathrm{~N}_{2} \mathrm{O}_{2}\right)\left(\mathrm{C}_{2} \mathrm{H}_{3} \mathrm{O}_{2}\right)$. These mixed complexes of zinc is prepared by reaction of $\mathrm{HL}\left(\mathrm{C}_{10} \mathrm{H}_{9} \mathrm{~N}_{2} \mathrm{O}_{4}\right)$ and $\mathrm{L}_{1}, \mathrm{~L}_{2}, \mathrm{~L}_{3}, \mathrm{~L}_{4}, \mathrm{~L}_{5}$ in ethanol solution.

Keywords: N-(2-propionic acid) salicyloyl hydrazone, 3, 5-dimethylpyrazole, 8-hydroxyquinoline
\end{abstract}

RASĀYAN J. Chem., Vol. 14, No.2, 2021

\section{INTRODUCTION}

Hydrazone Schiff base has been exhibited significant attention for appealing chemical behaviour ${ }^{1-2}$ and Biological essentiality. ${ }^{2-5}$ The coordination ability of hydrazone ligand through the $(\mathrm{N}, \mathrm{N}),(\mathrm{N}, \mathrm{S})$, and $(\mathrm{N}$, $\mathrm{O})$ donating atom that permits a multidentate or a bridging structural for transition and non-transition metal ions. Finally, many Zn (II) Schiff base complexes have been proposed and the geometry of these complexes because of the ligand donor set. ${ }^{6,7}$ The ligands are strong field tridentate ligands that build exceed chelating with zinc transition metals. In present paper reports synthesis and characterization of Schiff base ligands $\left(\mathrm{C}_{10} \mathrm{H}_{9} \mathrm{~N}_{2} \mathrm{O}_{4}\right)$ from modified method and formation of few new complexes of zinc:

1. $\mathrm{Zn}\left(\mathrm{C}_{5} \mathrm{H}_{5} \mathrm{~N}\right)\left(\mathrm{C}_{10} \mathrm{H}_{9} \mathrm{~N}_{2} \mathrm{O}_{4}\right) \mathrm{C}_{2} \mathrm{H}_{3} \mathrm{O}_{2}$

2. $\mathrm{Zn}\left(\mathrm{C}_{10} \mathrm{H}_{8} \mathrm{~N}_{2}\right)\left(\mathrm{C}_{10} \mathrm{H}_{9} \mathrm{~N}_{2} \mathrm{O}_{4}\right)$

3. $\mathrm{Zn}\left(\mathrm{C}_{5} \mathrm{H}_{8} \mathrm{~N}_{2}\right)_{3}\left(\mathrm{C}_{10} \mathrm{H}_{9} \mathrm{~N}_{2} \mathrm{O}_{4}\right)$

4. $\mathrm{Zn}\left(\mathrm{C}_{10} \mathrm{H}_{9} \mathrm{~N}_{2} \mathrm{O}_{4}\right)\left(\mathrm{C}_{9} \mathrm{H}_{6} \mathrm{NO}\right)\left(\mathrm{H}_{4} \mathrm{O}_{2}\right)$

5. $\mathrm{Zn}\left(\mathrm{C}_{10} \mathrm{H}_{9} \mathrm{~N}_{2} \mathrm{O}_{4}\right)\left(\mathrm{C}_{14} \mathrm{H}_{11} \mathrm{~N}_{2} \mathrm{O}_{2}\right)\left(\mathrm{C}_{2} \mathrm{H}_{3} \mathrm{O}_{2}\right)$.

It was an analysis of the behaviour of ligands specific to the transition metal. We report here in the synthesis, characterization of ligands:

L1: Pyridine,

L2:2, 2-bipyridyl

L3: 3, 5-dimethyl pyrazole,

L4: 8-Hydroxyquinoline

L5: Salicylazine.

The synthesized new compounds are identified and examined by elemental analysis, IR and mass spectroscopy.

\section{EXPERIMENTAL}

\section{Materials}

The solvents ethanol and diethylether were dried and use the standard method for distillation. All chemicals and solvents were purchased at Aldrich and used without purification. Chemicals were purchased from E Merk India. Water used in the reactions was distilled before use.

\section{Physical Measurements}

Pyruvic acid was a biochemical reagent; LB culture medium was formed in our laboratory. All the chemicals used in the laboratory were AR grade. The following instrumental methods were used for the characterization of the compounds in the present investigation. Infrared spectra of the ligand and their 
RASĀYAN J. Chem.

Vol. 14 | No. 3 |1514-1520| July - September | 2021

complexes were recorded with the help of For Infrared spectra, FTIR-SHIMADZU spectrophotometer on $\mathrm{KBr}$ pellets has been used for investigation of ligand and metal complex.

\section{General Procedure for Ligand and Complex \\ Synthesis of Schiff Base Ligand}

The ligand pyruvic acid-salicylhydrazone $\left(\mathrm{C}_{10} \mathrm{H}_{10} \mathrm{~N}_{2} \mathrm{O}_{4}\right)$ was synthesized following the reported method ${ }^{8}$. To a solution of salicyloylhydrazide $(6.09 \mathrm{~g})$ in anhydrous alcohol $(30 \mathrm{ml})$ was added in pyruvic acid (84 $\mathrm{ml})$. The reaction mixture was stirred on a water bath $\left(80^{\circ} \mathrm{C}\right)$ for $2 \mathrm{~h}$. The precipitate was filtered from the reaction mixture which was recrystallized from alcohol and washed by ether. After removal of the solvent water by evaporation, the precipitate was collected. The melting point is $216-217^{\circ} \mathrm{C}$. The ligand (HL) was obtained $\left[\mathrm{C}_{10} \mathrm{H}_{10} \mathrm{~N}_{2} \mathrm{O}_{4}\right]$. The ligands are characterized by mass spectroscopy, melting point and IR spectroscopy. M.p. $217-218{ }^{\circ} \mathrm{C} \operatorname{IR}\left(\mathrm{cm}^{-1}\right), v(\mathrm{OH}) ; 3750, v(\mathrm{C}=\mathrm{O}) ; 1725, v(\mathrm{Ar}-\mathrm{H}) ; 3100$.<smiles>NNC(=O)c1ccccc1O</smiles>

2- HBH Pyruvic acid<smiles>CC(=O)C(=O)O</smiles>

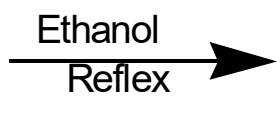

Pyruvic acid salicyolhydrazide

Scheme-1

Preparation of mixed Ligand Zinc Complex

Mixed Zinc Complex of Pyridine and HL

$\mathrm{Zn}\left(\mathrm{CH}_{3} \mathrm{COO}\right)_{2} .2 \mathrm{H}_{2} \mathrm{O}(0.183 \mathrm{~g} / \mathrm{mole}, 1 \mathrm{mmol})$ was dissolved in $5 \mathrm{ml}$ methanol and added drop by drop pyridine $(0.079 \mathrm{~g}, 1 \mathrm{mmole})$ into a stirred solution of zinc acetate. Pyruvate acid salicyl hydrazide in $10 \mathrm{ml}$ methanol $(0.222 \mathrm{~g}, 1 \mathrm{mmole})$ with continuously stirring was mixed. Stirring was continued overnight at $50^{\circ} \mathrm{C}$ and gray a crystalline precipitate of complex, which was filtered off, washed with acetone and ethanol. Colour: White, Yield:33\%, Zn 24.90\%, C 38.88\%, H 3.83\%, N 8.00\%, O 24.37\%, IR( $\left(\mathrm{cm}^{-1}\right), v$ $(\mathrm{OH}) ; 3750, v(\mathrm{C}=\mathrm{O}) ; 1610,(\mathrm{C}=\mathrm{C}) ; 1475, v(\mathrm{C}=\mathrm{N}) ; 1525, v(\mathrm{COO}-) \mathrm{s} ; 1330 ; v(\mathrm{Ar}-\mathrm{H}) ; 3105 ; v(\mathrm{M}-\mathrm{N}) ; 520, v(\mathrm{M}-$ O);420.

\section{Mixed Zinc Complex of 2-2-bipyridine and HL}

The complexes were synthesized by 1:1:1 molar ratio of reacting metal salts with the ligands, i.e. .one mole of zinc acetate dihydrate: one mole of pyruvic acid salicyolhydrazide, one mole of 2, 2'-bipyridine. The complex was prepared by adding dropwise a solution of 2,2'-bipyridine $(0.156 \mathrm{~g}, 1 \mathrm{mmole})$ in $10 \mathrm{ml}$ of methanol to a solution of $\mathrm{Zn}\left(\mathrm{CH}_{3} \mathrm{COO}\right)_{2} .2 \mathrm{H}_{2} \mathrm{O}(0.183 \mathrm{~g}, 1.0 \mathrm{mmol})$ while stirring magnetically at room temperature. To the above homogenous solution was added pyruvic acid salicylhydrazide $(0.111 \mathrm{~g}$, $1 \mathrm{mmol})$ in, $10 \mathrm{ml}$ of methanol drop wise while still stirring. In the reaction, stirring was uninterrupted overnight and the resulting precipitate of the complex was obtained which was filtered off, washed with acetone and ethanol. Colour: White, Yield:25\%, Zn22.30\%, C 45.07\%, H 3.95\%, N 9.55\%, O19.10\%, $\operatorname{IR}\left(\mathrm{cm}^{-1}\right), v(\mathrm{OH}) ; 3750, v(\mathrm{C}=\mathrm{N}) ; 1645, v(\mathrm{COO}-) \mathrm{s} ; 1340, v(\mathrm{Ar}-\mathrm{H}) ; 2955 ; v(\mathrm{M}-\mathrm{N}) ; 510, v(\mathrm{M}-\mathrm{O}) ; 425$.

\section{Mixed Zinc Complex of tris-(3,5-dimethylpyrazole) and HL}

zinc acetate dehydrate $\mathrm{Zn}\left(\mathrm{CH}_{3} \mathrm{COO}\right)_{2} \cdot 2 \mathrm{H}_{2} \mathrm{O}(.183 \mathrm{gm} / \mathrm{mole}, 1 \mathrm{mmole})$ dissolve in $10 \mathrm{ml}$ methanol and with continuously stirring add methanol solution of 3,5-dimethylpyrazole $(.288 \mathrm{gm} / \mathrm{mole})$. Simultaneously in two to three minutes, add pryuvic acid salicyloylhydrazide $(.222 \mathrm{gm} / \mathrm{mole})$ in methanol $(10-15 \mathrm{ml})$ in above solution. Stirring was continued for overnight and the resulting precipitate of complex was obtained. Colour: White, Yield:28\%, Zn $24.11 \%$, C37.66\%, H 4.27\%, N 10.33\%,O23.60\%, IR( $\left(\mathrm{cm}^{-1}\right)$, $v(\mathrm{OH}) ; 3750, \quad v(\mathrm{C}=\mathrm{C}) ; 1470, \quad v(\mathrm{C}=\mathrm{O}) ; 1691 \quad v(\mathrm{C}=\mathrm{N}) ; 1645, v(\mathrm{COO}-) \mathrm{s} ; 1340 ; v(\mathrm{Ar}-\mathrm{H}) ; 2945 ; \quad v(\mathrm{M}-\mathrm{N}) ; 510$, $v(\mathrm{M}-\mathrm{O}) ; 425$ 
RASĀYAN J. Chem.

Vol. 14 | No. 3 |1514-1520| July - September | 2021

\section{Mixed Zinc Complex of 8-hydroxyquinoline and HL}

One mole of metal salt zinc acetate dehydrate: one mole of pyruvic acid salicyolhydrazide: one moles of 8 -hydroxyquinoline was using in this reaction process. For example, the mixed metal salt was prepared by adding drop wise a solution of 8-hydroxyquinoline (.145 gm/mole, 1mmole) in $10 \mathrm{ml}$ of methanol. $\mathrm{Zn}\left(\mathrm{CH}_{3} \mathrm{COO}\right)_{2} 2 \mathrm{H}_{2} \mathrm{O}(0.183 \mathrm{gm} / \mathrm{mole}, 1 \mathrm{mmol})$ in $10 \mathrm{ml}$ of methanol was added to the above mixture with the simultaneously stirring at room temperature. In the above solution, pyruvic acid salicyol hydrazide $(0.222 \mathrm{~g}, 1 \mathrm{mmol})$ in $10 \mathrm{ml}$ of methanol was dropwise added while still.Stirring was continued overnight and filtered. The Precipitatedis obtained and recrystallized. Colour: Off White, Yield:25\%, Zn $14.00 \%$, $\mathrm{C} 48.89 \%, \mathrm{H} 4.10 \%, \mathrm{~N} 9.00 \%, \mathrm{O} 23.99 \%, \mathrm{IR}\left(\mathrm{cm}^{-1}\right), v(\mathrm{NH}) ; 3740, v(\mathrm{C}=\mathrm{N}) ; 1675, v(\mathrm{COO}-)$ as $1530 ;, v(\mathrm{COO}-$ ) $\mathrm{s} ; 1300, v\left(\mathrm{~V}_{\mathrm{as}}-\mathrm{V}_{\mathrm{s}}\right) 230 ; \mathrm{v}(\mathrm{Ar}-\mathrm{H}) ; 3070 ; \mathrm{v}(\mathrm{M}-\mathrm{N}) ; 560, v(\mathrm{M}-\mathrm{O}) ; 430$.

\section{Mixed Zinc Complex of Salicylaldehydeazine and HL}

To proceed with this reaction, a 1; 1; 1 molar ratio of ligands and metal salts was used, i.e. one mole of metal salt zinc acetate dihydrate: one mole of sodium pyruvate salicyolhydrazide: one mole of salicylaldehydeazine. The mixed metal salt was prepared by adding dropwise a solution of salicylaldehyde azine $(.240 \mathrm{gm} 1 \mathrm{mmol})$ in $10 \mathrm{ml}$ of methanol and a solution of $\mathrm{Zn}\left(\mathrm{CH}_{3} \mathrm{COO}\right)_{2} 2 \mathrm{H}_{2} \mathrm{O}(0.183$ gm 1mmol) in $10 \mathrm{ml}$ of methanol while stirring magnetically at room temperature. After 15 minutes mathanolic solution of pyruvic acid salicyolhydrazide was added and reaction mixture reflex for overnight. Precipitated is obtained and filtrate kept for 5-6 days crystalline compound appeared. This compound is characterized by mass spectra. Colour: Palm Yellow, Yield: $30 \%$, Zn 11.55\%, C 50.94\%, H $3.74 \%, \mathrm{~N} 9.90 \%, \mathrm{O} 19.75 \%, \mathrm{IR}\left(\mathrm{cm}^{-1}\right), v(\mathrm{NH}) ; 3740, v(\mathrm{C}=\mathrm{N}) ; 1675, v(\mathrm{COO}-)$ as $1530 ;, v(\mathrm{CO}) \mathrm{s} ; 1300, v\left(\mathrm{Vas}^{-}\right.$ $\left.\mathrm{V}_{\mathrm{s}}\right) 230 ; \mathrm{v}(\mathrm{Ar}-\mathrm{H}) ; 3070 ; \mathrm{v}(\mathrm{M}-\mathrm{N}) ; 560, v(\mathrm{M}-\mathrm{O}) ; 430$.

\section{Structure of Zinc mixed ligands Complex}

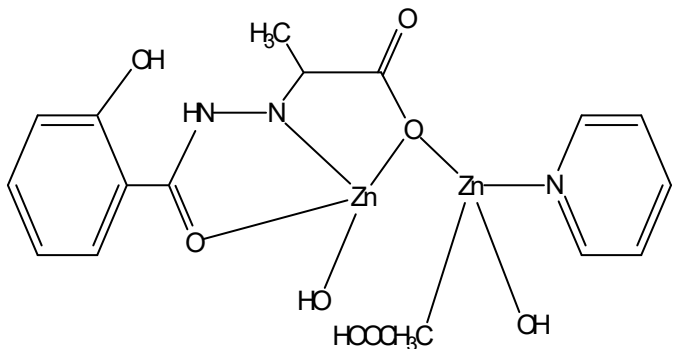

1. $\mathrm{Zn}\left(\mathrm{C}_{5} \mathrm{H}_{5} \mathrm{~N}\right)\left(\mathrm{C}_{10} \mathrm{H}_{9} \mathrm{~N}_{2} \mathrm{O}_{4}\right) \mathrm{C}_{2} \mathrm{H}_{3} \mathrm{O}_{2}$<smiles>Cc1cc(C)n([Z20](C)(O)O[Z10](O)(O)C(=O)NN2OC(=O)C2C)n1</smiles>

3. $\mathrm{Zn}_{2}\left(\mathrm{C}_{5} \mathrm{H}_{8} \mathrm{~N}_{2}\right)\left(\mathrm{C}_{10} \mathrm{H}_{9} \mathrm{~N}_{2} \mathrm{O}_{4}\right)(\mathrm{OH})_{2} . \mathrm{C}_{2} \mathrm{H}_{4} \mathrm{O}_{2}$

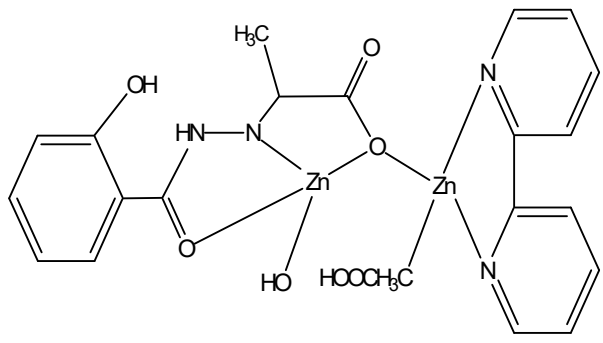

2. $\mathrm{Zn}\left(\mathrm{C}_{10} \mathrm{H}_{8 \mathrm{~N}_{2}}\right)\left(\mathrm{C}_{10} \mathrm{H}_{9} \mathrm{~N}_{2} \mathrm{O}_{4}\right)$

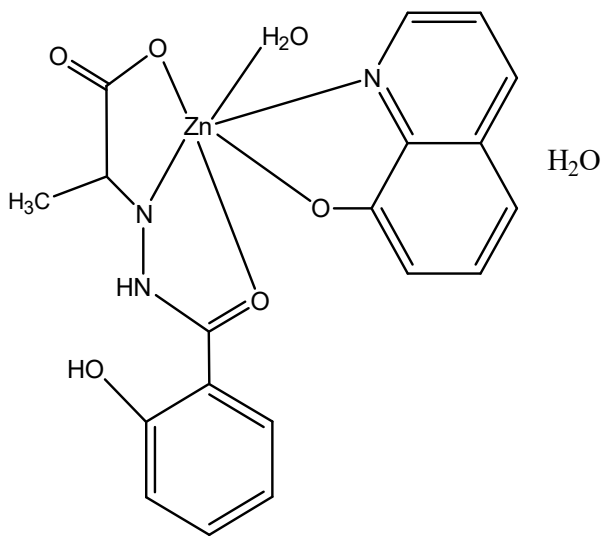

4. $\mathrm{Zn}\left(\mathrm{C}_{10} \mathrm{H}_{9} \mathrm{~N}_{2} \mathrm{O}_{4}\right)\left(\mathrm{C}_{9} \mathrm{H}_{6} \mathrm{NO}\right)\left(\mathrm{H}_{4} \mathrm{O}_{2}\right)$ 
RASĀYAN J. Chem.

Vol. 14 | No. 3 |1514-1520| July - September | 2021

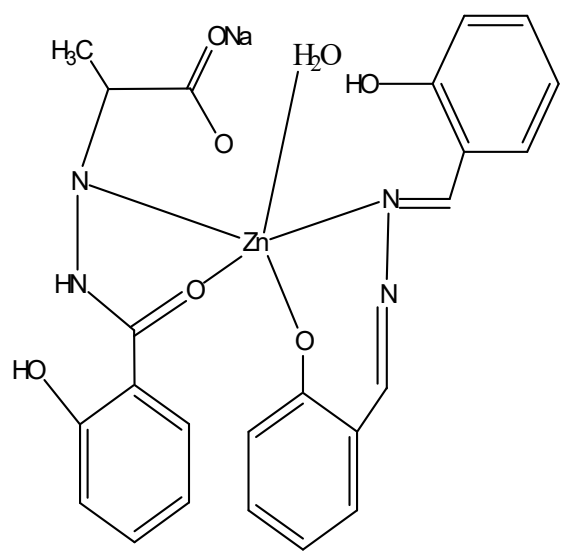

5. $\mathrm{Zn}\left(\mathrm{C}_{10} \mathrm{H}_{8} \mathrm{~N}_{2} \mathrm{O}_{4}\right)\left(\mathrm{C}_{14} \mathrm{H}_{11} \mathrm{~N}_{2} \mathrm{O}_{2}\right) \mathrm{Na}_{2} \mathrm{H}_{2} \mathrm{O}$

Fig.-1: Structures of Zinc Complexes

\section{AntimicrobialActivity}

The test compounds under study were dissolved in Methanol the concentration of the stock solution was made $6 \mathrm{mg} / \mathrm{ml}$. The $50 \mu \mathrm{l}$ of test compound was utilized in every well. Streptomycin was applied as a positive control $(5 \mathrm{mg} / \mathrm{ml}$ concentration) for antibacterial activity and itraconazol was used against Aspergillus fumigates. Mueller-Hinton agar medium and Sabouraud dextrose agar medium is the only susceptibility test medium that has been validated by CLSI for screening the antimicrobial activity by disk/ well diffusion susceptibility testing. Fresh Cultures of test isolates of Escherichia coli, and Aspergillus fumigates were inoculated in Peptone water and Sabouraud dextrose broth respectively and were held for incubation for 30 minutes at $37^{\circ} \mathrm{C}$. The inoculum size of bacteria was adjusted using the McFarland turbidity standard as reference. A Comparison was held between the bacterial or fungal suspensions and 0.5 McFarland Turbidity Standard. Bacterial cultures were swabbed onto the Mueller Hinton Agar surface and Aspergillus fumigatus were swabbed onto the Sabouraud dextrose agar surface. The different test solutions were loaded into the wells. $50 \mu \mathrm{l}$ from different dilutions prepared from stock was loaded into the respective wells. The bacterial and Aspergillus fumigatus plates were retained for incubation at $37^{\circ} \mathrm{C}$ for one day for bacterial and 3-4 days for Aspergillus fumigates.

\section{RESULTS AND DISCUSSION}

There were some remarkable changes between the zinc (II) complexes and free ligands for chelation as anticipated. Ir spectra of complex $Z_{1}, Z_{2}, Z_{4}, Z_{5}$, are a shift in imnic $v C=N$ to a higher frequency and appeared at (1630-1670) $\mathrm{cm}^{-1}$ that comparison with free ligand. ${ }^{9}$ The Ir spectra of complex $Z_{3}$ are a shift in imnic $v(\mathrm{C}=\mathrm{N})$ to lower frequency and appeared at $(1610-1620) \mathrm{cm}^{-1}$ that comparison with free ligand. ${ }^{10}$ The frequency of azomethine band was shifted in all-metal complexes, suggesting that the nitrogen atom was coordinated to the metal atom. ${ }^{11-13}$ The nitrogen atom coordinate to metal atom was foreseen to curtail the electron density for the azomethine and that case $70 \mathrm{~cm}^{-1}$ shift in the $\mathrm{C}=\mathrm{N}$ band. The broad absorption in the spectra of all zinc complexes in region $3750 \mathrm{~cm}^{-1}$ assigning to $\mathrm{v}(\mathrm{O}-\mathrm{H})$ of a coordinated water molecule in the inner sphere of the metal complex. From the above examination, it is clear that the metal ions are coordinated with the Schiff base ligand through the carbonyl oxygen and the azomethine nitrogen.

Table-1: IR Spectra of Zinc mixed Ligand Complexes

\begin{tabular}{c|c|c|c|c|c|c|c|c|c}
\hline S.No. & $v \mathrm{OH}$ & $v(\mathrm{C}=\mathrm{C})$ & $v(\mathrm{C}=\mathrm{O})$ & $v(\mathrm{C}=\mathrm{N})$ & $v\left(\mathrm{COO}^{-}\right) \mathrm{s}$ & $\Delta v(\mathrm{Ar}-\mathrm{H})$ & $v(C-H)$ & $M-N$ & $M-O$ \\
\hline 1. & 3750 & 1470 & 1685 & 1645 & 1340 & 2955 & $730,755,830$ & 510 & 425 \\
\hline 2. & 3750 & 1470 & 1690 & 1645 & 1340 & 2945 & $700,725,760$ & 510 & 425 \\
\hline 3. & 3750 & 1475 & 1750 & 1525 & 1330 & 3025 & $730,750,805$ & 520 & 425 \\
\hline 4 & 3750 & 1460 & 1670 & 1620 & 1360 & 2900 & $700,750,780$ & 505 & 425 \\
\hline 5 & 3750 & 1475 & 1750 & 1640 & 1330 & 2950 & 750,775 & 505 & 425 \\
\hline
\end{tabular}

In the low-frequency region, All the new formed Zinc complex show some new spectra band in region 505-449 and 425-401 $\mathrm{cm}^{-1}$ has been assigned to $v(\mathrm{M}-\mathrm{O})$ and $v(\mathrm{M}-\mathrm{N})$ respectively. The band owing to ring 
RASĀYAN J. Chem.

Vol. 14 | No. 3 |1514-1520| July - September | 2021

vibration of 2, 2'bipyidine remarked at $1621 \mathrm{~cm}^{-1}$ was shifted to $1585-1591 \mathrm{~cm}^{-1}$ in the complex. ${ }^{14}$ In $\mathrm{Z}_{2}$ complex 2,2-bipyridine coordinate to Zinc ion is described by a shift in frequency by $33 \mathrm{~cm}^{-1}$. All the compounds have been $\mathrm{C}-\mathrm{H}$ and $\mathrm{C}=\mathrm{C}$ stretching bands sustain coordination and emphasized decreases in

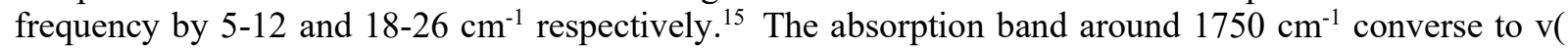
$\mathrm{C}=\mathrm{O}) \mathrm{COOH}$ of free HL has been displaced by two bands $v_{\mathrm{s}} \mathrm{COO}-, v_{\text {as }} \mathrm{COO}-$ and the $\left(v_{\text {as }}\right)$ are $1330 \mathrm{~cm}^{-}$ ${ }^{1}$.The carbonyl signal of the free ligand is shifted from $1690 \mathrm{~cm}^{-1}$ to $1650 \mathrm{~cm}^{-1}$ in the complex. This examination is showing that the Zinc (II) ion could be coordinated withan oxygen atom.

A medium intensity band at $3309 \mathrm{~cm}^{-1}$ is ascribed to the $\mathrm{N}-\mathrm{H}$ stretching vibration of the imino group; while another vibration at $954 \mathrm{~cm}^{-1}$ is described to $\mathrm{m}(\mathrm{N}-\mathrm{N})$ vibrations. ${ }^{16-19}$ The carbonyl group shows a stretching vibration band at $1665-1690 \mathrm{~cm}^{-1}$. All comparison of the spectra of HL with its metal complexes approves to conclude the coordinating atoms in all the species. In the complex's formation, $\mathrm{HL}$ acts as a tridentate ligand, in which the azomethine nitrogen $(\mathrm{C}=\mathrm{N})$ and the oxygen atom of the $\mathrm{C}=\mathrm{O}$ group show coordination. The IR band frequencies of the ligands and metal complexes are representing in Table-1. The exchanged shifts in-band frequencyis a fine intimation that ligands are coordinated to the respective zinc metal. The comparative study of the IR, mass spectra of the ligand and metal complex of those of the corresponding compound, intimate that ligands are coordinated to metal ions giving zinc complexes.

\section{Mass spectra ofZinc mixed Ligand Complex}

The FAB mass spectral studies of five zinc compounds $\left[\mathrm{Zn}\left(\mathrm{C}_{10} \mathrm{H}_{9} \mathrm{O}_{4} \mathrm{~N}_{2}\right]\right.$ indicate tridented nature. The molecular ion peak of the compound appears, that confirming the formation of a metal complex in 1:1:1, $1: 1: 2$, ratio. Owing to the re-association of fragments ion, some molecular ion peaks at higher $\mathrm{m} / \mathrm{z}$ than molecular ion peak were observed. The splitting patterns of mass spectra of the complexes are presented in the following Table-2.

\begin{tabular}{c|c|c} 
Table-2: Mass fragmentation of Zinc Complexes \\
Compound & Fragment Ion & m/z Value \\
\hline $1 . \mathrm{Zn}_{2}\left(\mathrm{C}_{10} \mathrm{H}_{9} \mathrm{~N}_{2} \mathrm{O}_{4}\right)\left(\mathrm{C}_{5} \mathrm{H}_{5} \mathrm{~N}\right)\left(\mathrm{C}_{2} \mathrm{H}_{4} \mathrm{O}_{2}\right) \cdot(\mathrm{OH})_{2}$ & $\mathrm{Zn}_{2}\left(\mathrm{C}_{10} \mathrm{H}_{9} \mathrm{~N}_{2} \mathrm{O}_{4}\right)\left(\mathrm{C}_{5} \mathrm{H}_{5} \mathrm{~N}\right)\left(\mathrm{C}_{2} \mathrm{H}_{4} \mathrm{O}_{2}\right) \cdot(\mathrm{OH})_{2}$ & 525.11 \\
\hline & $\mathrm{Zn}_{2}\left(\mathrm{C}_{10} \mathrm{H}_{9} \mathrm{~N}_{2} \mathrm{O}_{4}\right)\left(\mathrm{C}_{5} \mathrm{H}_{5} \mathrm{~N}\right) \mathrm{C}_{2} \mathrm{H}_{4} \mathrm{O}_{2} . \mathrm{OH}$ & 508.10 \\
\hline & $\mathrm{Zn}_{2}\left(\mathrm{C}_{5} \mathrm{H}_{5} \mathrm{~N}\right)\left(\mathrm{C}_{7} \mathrm{H}_{7} \mathrm{~N}_{2} \mathrm{O}_{4}\right)\left(\mathrm{C}_{2} \mathrm{H}_{4} \mathrm{O}_{2} \cdot \mathrm{OH}\right.$ & 470.06 \\
\hline & $\mathrm{Zn}_{2}\left(\mathrm{C}_{5} \mathrm{H}_{5} \mathrm{~N}\right)\left(\mathrm{C}_{7} \mathrm{H}_{7} \mathrm{~N}_{2} \mathrm{O}_{4}\right)\left(\mathrm{C}_{2} \mathrm{H}_{4} \mathrm{O}_{2}\right) . \mathrm{OH}$ & 468.044 \\
\hline & $\mathrm{Zn}_{2}\left(\mathrm{C}_{5} \mathrm{H}_{5}\right)\left(\mathrm{C}_{4} \mathrm{H}_{4} \mathrm{~N}_{2} \mathrm{O}_{3}\right)\left(\mathrm{C}_{2} \mathrm{H}_{4} \mathrm{O}_{2}\right) . \mathrm{OH}$ & 415.00 \\
\hline & $\mathrm{Zn}_{2}\left(\mathrm{C}_{5} \mathrm{H}_{5} \mathrm{~N}\right)\left(\mathrm{C}_{2} \mathrm{H}_{3} \mathrm{~N}_{2} \mathrm{O}_{3}\right)\left(\mathrm{C}_{2} \mathrm{H}_{4} \mathrm{O}_{2}\right) . \mathrm{OH}$ & 414.00 \\
\hline & $\mathrm{Zn}_{2}\left(\mathrm{C}_{5} \mathrm{H}_{5} \mathrm{~N}\right)\left(\mathrm{C}_{2} \mathrm{H}_{4} \mathrm{O}_{2}\right) \cdot \mathrm{OH} \cdot \mathrm{C}_{4} \mathrm{~N}_{2} \mathrm{H}_{4} \mathrm{O}_{2}$ & 413.00 \\
\hline & $\mathrm{Zn}_{2}\left(\mathrm{C}_{5} \mathrm{H}_{5} \mathrm{~N}\right)\left(\mathrm{C}_{2} \mathrm{H}_{2} \mathrm{~N}_{2} \mathrm{O}_{3}\right)\left(\mathrm{C}_{2} \mathrm{H}_{4} \mathrm{O}_{2}\right) . \mathrm{OH}$ & 412.99 \\
\hline & $\mathrm{Zn}_{2} \mathrm{O}\left(\mathrm{C}_{5} \mathrm{H}_{5} \mathrm{~N}\right)\left(\mathrm{C}_{2} \mathrm{H}_{4} \mathrm{O}_{2}\right) \mathrm{OH}$ & 301.91 \\
\hline & $\mathrm{Zn}$ & 146 \\
\hline
\end{tabular}

\begin{tabular}{l|c|c}
\hline $2 . \mathrm{Zn}_{2}\left(\mathrm{C}_{5} \mathrm{H}_{5} \mathrm{~N}\right)_{2}\left(\mathrm{C}_{10} \mathrm{H}_{9} \mathrm{~N}_{2} \mathrm{O}_{4}\right) \mathrm{OH} . \mathrm{C}_{2} \mathrm{H}_{4} \mathrm{O}_{2}$ & $\mathrm{Zn}_{2}\left(\mathrm{C}_{5} \mathrm{H}_{5} \mathrm{~N}_{2}\left(\mathrm{C}_{10} \mathrm{H}_{9} \mathrm{~N}_{2} \mathrm{O}_{4}\right) \mathrm{OH}_{2} \mathrm{C}_{2} \mathrm{H}_{4} \mathrm{O}_{2}\right.$ & 586 \\
\hline & $\mathrm{Zn}_{2}\left(\mathrm{C}_{5} \mathrm{H}_{5} \mathrm{~N}\right)_{2}\left(\mathrm{C}_{10} \mathrm{H}_{9} \mathrm{~N}_{2} \mathrm{O}_{4}\right) . \mathrm{CO}_{3} \mathrm{H}$ & 568.2 \\
\hline & $\mathrm{Zn}_{2}\left(\mathrm{C}_{5} \mathrm{H}_{5} \mathrm{~N}_{2}\left(\mathrm{C}_{10} \mathrm{H}_{9} \mathrm{~N}_{2} \mathrm{O}_{4}\right) . \mathrm{OH}\right.$ & 523.2 \\
\hline & $\mathrm{Zn}_{2}\left(\mathrm{C}_{5} \mathrm{H}_{5} \mathrm{~N}_{2}\left(\mathrm{C}_{10} \mathrm{H}_{9} \mathrm{~N}_{2} \mathrm{O}_{4}\right)\right.$ & 506 \\
\hline & $\mathrm{Zn}_{2}\left(\mathrm{C}_{5} \mathrm{H}_{5} \mathrm{~N}_{2}\left(\mathrm{C}_{4} \mathrm{H}_{5} \mathrm{~N}_{2} \mathrm{O}_{3}\right)\right.$ & 414.8 \\
\hline & $\mathrm{Zn}_{2}\left(\mathrm{C}_{5} \mathrm{H}_{5} \mathrm{~N}_{2}\left(\mathrm{C}_{4} \mathrm{H}_{4} \mathrm{~N}_{2} \mathrm{O}_{3}\right)\right.$ & 361 \\
\hline & $\mathrm{Zn}_{2}\left(\mathrm{C}_{5} \mathrm{H}_{5} \mathrm{~N}_{2}\left(\mathrm{C}_{2} \mathrm{H}_{3} \mathrm{O}_{2}\right) . \mathrm{OH}\right.$ & 359 \\
\hline & $\mathrm{Zn}_{2}\left(\mathrm{C}_{5} \mathrm{H}_{5} \mathrm{~N}_{2}\left(\mathrm{C}_{2} \mathrm{H}_{2} \mathrm{O}_{2}\right) . \mathrm{OH}\right.$ & 318. \\
\hline & $\mathrm{Zn}_{2}\left(\mathrm{C}_{5} \mathrm{H}_{5} \mathrm{~N}_{2}\left(\mathrm{C}_{2} \mathrm{HO}_{2}\right) . \mathrm{OH}\right.$ & 318.2 \\
\hline & $\mathrm{Zn}_{2} \mathrm{O}_{2}\left(\mathrm{C}_{5} \mathrm{H}_{5} \mathrm{~N}_{2} . \mathrm{OH}\right.$ & 301 \\
\hline & $\mathrm{Zn}_{2}\left(\mathrm{C}_{2} \mathrm{H}_{2} \mathrm{NO}_{2}\right)\left(\mathrm{C}_{5} \mathrm{H}_{8} \mathrm{~N}_{2}\right)(\mathrm{OH})_{2}$ & 187 \\
\hline & $\mathrm{Zn}_{2} \mathrm{O}\left(\mathrm{C}_{5} \mathrm{H}_{5} \mathrm{~N}_{2}\right.$ & 186 \\
\hline & $\mathrm{Zn}_{2}\left(\mathrm{HC}_{2} \mathrm{O}_{2}\right)$ & 146 \\
\hline & $\mathrm{Zn}_{2}\left(\mathrm{C}_{2} \mathrm{O}_{2}\right)$ & \\
\hline & $\mathrm{Zn}_{2}(\mathrm{O})$ & \\
\hline
\end{tabular}


RASĀYAN J. Chem.

Vol. 14 | No. 3 |1514-1520| July - September | 2021

\begin{tabular}{|c|c|c|}
\hline $3 . \mathrm{Zn}_{2}\left(\mathrm{C}_{5} \mathrm{H}_{8} \mathrm{~N}_{2}\right)\left(\mathrm{C}_{10} \mathrm{H}_{9} \mathrm{~N}_{2} \mathrm{O}_{4}\right)(\mathrm{OH})_{2} \cdot \mathrm{C}_{2} \mathrm{H}_{4} \mathrm{O}_{2}$ & $\mathrm{Zn}_{2}\left(\mathrm{C}_{10} \mathrm{H}_{9} \mathrm{~N}_{2} \mathrm{O}_{4}\right)\left(\mathrm{C}_{5} \mathrm{H}_{8} \mathrm{~N}_{2}\right)(\mathrm{HO})_{2} \cdot \mathrm{C}_{2} \mathrm{H}_{4} \mathrm{O}_{2}$ & 543 \\
\hline & $\mathrm{Zn}_{2}\left(\mathrm{C}_{10} \mathrm{H}_{9} \mathrm{~N}_{2} \mathrm{O}_{4}\right)\left(\mathrm{C}_{5} \mathrm{H}_{8} \mathrm{~N}_{2}\right)(\mathrm{OH})_{2}$ & 483 \\
\hline & $\mathrm{Zn}_{2}\left(\mathrm{C}_{10} \mathrm{H}_{9} \mathrm{~N}_{2} \mathrm{O}_{4}\right)\left(\mathrm{C}_{5} \mathrm{H}_{8} \mathrm{~N}_{2}\right) \cdot \mathrm{OH}$ & 466 \\
\hline & $\mathrm{Zn}_{2}\left(\mathrm{C}_{6} \mathrm{H}_{7} \mathrm{~N}_{2} \mathrm{O}_{4}\right)\left(\mathrm{C}_{5} \mathrm{H}_{8} \mathrm{~N}_{2}\right) \mathrm{OH}$ & 415.13 \\
\hline & $\left.\mathrm{Zn}_{2}\left(\mathrm{C}_{6} \mathrm{H}_{6} \mathrm{~N}_{2} \mathrm{O}_{4}\right) \mathrm{C}_{5} \mathrm{H}_{8} \mathrm{~N}_{2}\right) \mathrm{OH}$ & 414.13 \\
\hline & $\mathrm{Zn}_{2}\left(\mathrm{C}_{2} \mathrm{H}_{2} \mathrm{O}_{2} \mathrm{~N}\right)\left(\mathrm{C}_{5} \mathrm{H}_{8} \mathrm{~N}_{2}\right)(\mathrm{OH})_{2}$ & 318.13 \\
\hline & $\mathrm{Zn}_{2}\left(\mathrm{C}_{2} \mathrm{H}_{2} \mathrm{O}_{2} \mathrm{~N}\right)\left(\mathrm{C}_{5} \mathrm{H}_{8} \mathrm{~N}_{2}\right)\left(\mathrm{H}_{2} \mathrm{O}\right)$ & 301.13 \\
\hline & $\mathrm{Zn}_{2}\left(\mathrm{C}_{2} \mathrm{HO}_{2}\right)$ & 187 \\
\hline & $\mathrm{Zn}_{2}\left(\mathrm{C}_{2} \mathrm{O}_{2}\right)$ & 186 \\
\hline & $\mathrm{Zn}_{2}(\mathrm{O})$ & 146 \\
\hline \multirow[t]{2}{*}{$4 . \mathrm{Zn}\left(\mathrm{C}_{10} \mathrm{H}_{9} \mathrm{~N}_{2} \mathrm{O}_{4}\right)\left(\mathrm{C}_{9} \mathrm{H}_{6} \mathrm{NO}\right)\left(\mathrm{H}_{4} \mathrm{O}_{2}\right)$} & $\mathrm{Zn}\left(\mathrm{C}_{10} \mathrm{H}_{9} \mathrm{~N}_{2} \mathrm{O}_{4}\right)\left(\mathrm{C}_{9} \mathrm{H}_{6} \mathrm{NO}\right)\left(\mathrm{H}_{2} \mathrm{O}\right)_{2}$ & 466.75 \\
\hline & $\mathrm{Zn}\left(\mathrm{C}_{9} \mathrm{H}_{6} \mathrm{NO}\right)$ & 211.6 \\
\hline \multirow[t]{6}{*}{$5 . \mathrm{Zn}\left(\mathrm{C}_{10} \mathrm{H}_{9} \mathrm{~N}_{2} \mathrm{O}_{4}\right)\left(\mathrm{C}_{14} \mathrm{H}_{11} \mathrm{~N}_{2} \mathrm{O}_{2}\right)$} & $\mathrm{Zn}\left(\mathrm{C}_{10} \mathrm{H}_{9} \mathrm{~N}_{2} \mathrm{O}_{4}\right)\left(\mathrm{C}_{14} \mathrm{H}_{11} \mathrm{~N}_{2} \mathrm{O}_{2}\right) \mathrm{Na} \cdot \mathrm{H}_{2} \mathrm{O}$ & 565.81 \\
\hline & $\mathrm{Zn}\left(\mathrm{C}_{10} \mathrm{H}_{9} \mathrm{~N}_{2} \mathrm{O}_{4}\right)\left(\mathrm{C}_{14} \mathrm{H}_{11} \mathrm{~N}_{2} \mathrm{O}_{2}\right) \cdot \mathrm{H}_{2} \mathrm{O}$ & 542.87 \\
\hline & $\mathrm{Zn}\left(\mathrm{C}_{10} \mathrm{H}_{7} \mathrm{~N}_{2} \mathrm{O}_{4}\right)\left(\mathrm{C}_{14} \mathrm{H}_{11} \mathrm{~N}_{2} \mathrm{O}_{2}\right) \cdot \mathrm{H}_{2} \mathrm{O}$ & 540.79 \\
\hline & $\mathrm{Zn}\left(\mathrm{C}_{9} \mathrm{H}_{7} \mathrm{~N}_{2} \mathrm{O}_{4}\right)\left(\mathrm{C}_{14} \mathrm{H}_{11} \mathrm{~N}_{2} \mathrm{O}_{2}\right) \cdot \mathrm{H}_{2} \mathrm{O}$ & 528.72 \\
\hline & $\mathrm{Zn}\left(\mathrm{C}_{9} \mathrm{H}_{7} \mathrm{~N}_{2} \mathrm{O}_{3}\right)\left(\mathrm{C}_{14} \mathrm{H}_{11} \mathrm{~N}_{2} \mathrm{O}_{2}\right)$ & 511.87 \\
\hline & $\mathrm{Zn}\left(\mathrm{C}_{9} \mathrm{H}_{7} \mathrm{~N}_{2} \mathrm{O}_{3}\right)\left(\mathrm{C}_{14} \mathrm{H}_{11} \mathrm{~N}_{2} \mathrm{O}_{2}\right)$ & 495.79 \\
\hline
\end{tabular}

\section{CONCLUSION}

The complex of $\mathrm{Zn}$ with bi and tridentate Schiff base of the $\mathrm{N}_{2} \mathrm{O}_{2}$ donor were prepared and characterized with IR, Mass, biological analysis. The Schiff base donor atom $\mathrm{N}$ and $\mathrm{O}$ have specific nature for a coordinate to the metal ion and show new complexation. This compound of the Zinc complex shows different nature and formed a bridged ( $\mathrm{Zn}-\mathrm{O}-\mathrm{Zn}$ ) Complex. The Zinc complexes are: $\mathrm{Zn}_{2}$ $\left(\mathrm{C}_{10} \mathrm{H}_{9} \mathrm{~N}_{2} \mathrm{O}_{4}\right)\left(\mathrm{C}_{5} \mathrm{H}_{5} \mathrm{~N}\right)\left(\mathrm{C}_{2} \mathrm{H}_{4} \mathrm{O}_{2}\right) \cdot(\mathrm{OH})_{2}, \mathrm{Zn}_{2}\left(\mathrm{C}_{10} \mathrm{H}_{8} \mathrm{~N}_{2}\right)\left(\mathrm{C}_{10} \mathrm{H}_{9} \mathrm{~N}_{2} \mathrm{O}_{4}\right) \mathrm{OH} \cdot \mathrm{C}_{2} \mathrm{H}_{4} \mathrm{O}_{2}, \mathrm{Zn}_{2}\left(\mathrm{C}_{5} \mathrm{H}_{8} \mathrm{~N}_{2}\right)\left(\mathrm{C}_{10} \mathrm{H}_{9} \mathrm{~N}_{2} \mathrm{O}_{4}\right)$ $(\mathrm{OH})_{2} \cdot \mathrm{C}_{2} \mathrm{H}_{4} \mathrm{O}_{2}, \mathrm{Zn}\left(\mathrm{C}_{10} \mathrm{H}_{9} \mathrm{~N}_{2} \mathrm{O}_{4}\right)\left(\mathrm{C}_{9} \mathrm{H}_{6} \mathrm{NO}\right)\left(\mathrm{H}_{4} \mathrm{O}_{2}\right), \mathrm{Zn}\left(\mathrm{C}_{10} \mathrm{H}_{9} \mathrm{~N}_{2} \mathrm{O}_{4}\right)\left(\mathrm{C}_{14} \mathrm{H}_{11} \mathrm{~N}_{2} \mathrm{O}_{2}\right)$ were proposed according to data obtained. As well the antifungal activity of the prepared complex was also screened against E.coli and aspergillus Fusarium and antimicrobial activity against Microbacterium tuberculosis bacteria.

\section{ACKNOWLEDGMENT}

The authors are thankful to the center for innovation, Research and Development (CIRD) Dr. B. Lal Institute of Biotechnology, Jaipur (Rajasthan) for carrying out the antimicrobial activity and also grateful to the University of Rajasthan for FAB Mass, IR Spectra of zinc complex.

\section{REFERENCES}

1. W. X. Ni, M. Li, S. Z. Zhan, J. Z. Hou, D. Li, Inorganic Chemistry, 48, 1433(2009), https://doi.org/10.1021/ic8015244

2. L. N. Dawe, L. K. Thompson, Dalton Transaction, 27, 3610(2008), https://doi.org/10.1039/B800529J

3. Y. Bae, N. Nishiyama, K. Kataoka, Bioconjugate Chemistry, 18, 1131(2007), https://doi.org/10.1021/bc060401p

4. V. Barve, F. Ahmed, S. Banerjee, S. KulKarni, P. Katiyar, C. E. Anson, A. K. Powell, S. Padhye, F. H. Sarkar, Journal of Medicinal Chemistry, $49,3800(2006)$, https://doi.org/10.1021/jm051068y

5. H. Gaertner, R. Offord, P. Botti, G. Kuenzi, O. Hartley, Bioconjugate Chemistry, 19, 480(2008), https://doi.org/10.1021/bc7003044

6. T. D. Thangadurai, and K. Natarajan, Synthesis and Reactivity in Inorganic and Metal-Organic Chemistry, 31(4), 549(2001), https://doi.org/10.1081/SIM-100104786

7. R. C. Sharma, and V. K. Varshney, Journal of Inorganic Biochemistry, 41, 299304(1991), https://doi.org/10.1016/0162-0134(91)80023-B

8. W. J. Geary, Coordination Chemistry Reviews, 7, 81(1971), https://doi.org/10.1016/S0010$\underline{8545(00) 80009-0}$ 
RASĀYAN J. Chem.

Vol. 14 | No. 3 |1514-1520| July - September | 2021

9. M. F. Farona, D.C. Perry, and H. A. Kuska, Inorganic Chemistry, 7(11), 2415(1968), https://doi.org/10.1021/ic50069a045

10. M. Shebl, Spectrochimica Acta A, 73, 313(2009), https://doi.org/10.1016/j.saa.2009.02.030

11. M. Patel, M.M. Patel, A. Ray, M. R. Patel, Journal of Inorganic and Nuclear Chemistry, 43, 509(1980), https://doi.org/10.1016/0022-1902(81)80492-7

12. S. Mayadevi, G.P. Preetha, K.K.M. Yusuff, Synthesis and Reactivity in Inorganic and Metal-Organic Chemisry, 33, 481(2003), https://doi.org/10.1081/SIM-120020000

13. S. M. Abdallah, G.G. Mohamed, M.A. Zayed, M.S. Abou El-Ela, Spectrochimica Acta Part A: $\begin{array}{lllll}\text { Molecular and } \quad \text { Biomolecular } & \text { Spectroscopy, } & \text { 73, } & \text { 833(2009), }\end{array}$ https://doi.org/10.1016/j.saa.2009.04.005

14. P. A. N. Reddy, M. Nethaji, A. R. Chakravarty, Inorganic Chimica Acta, 337, 450(2002), https://doi.org/10.1016/S0020-1693(02)01108-8

15. R. M. Silverstein, G. C. Bassler, T. C. Morril, Spectrometric Identification of Organic Compounds, 4th Ed., John Wiley and Sons, 1981.

16. K. Nakamoto, 3rd edition, Infrared and Raman spectra of Inorganic and CoordinationCompounds. Wiley, New York; 1997.

17. T. Premkumar, S. Govindarajan , World Journal of Microbiology and Biotechnology, 22, 105(2006), https://doi.org/10.1007/s11274-006-9149-x

18. B. N. Figgis, J. Lewis, Modern Coordination Chemistry, Ed. J. Lewis and R. G. Wilkins Interscience, New York, 1960, 403 and 406

19. J. C. Pessoa, I. Covcia, I. Correia, M T. Duarte, R. D. Gillard, R. T. Heneriques, F. J. Higes, C. Madeira and I. Thomaz, Inorganica Chimica Acta, 293, 1(1999), https://doi.org/10.1016/S00201693(99)00196-6

20. A. A. Schilt and R. C. Taylor, Journal of Inorganic and Nuclear Chemistry, 9, 211(1959), https://doi.org/10.1016/0022-1902(59)80224

[RJC-6301/2020] 